\title{
Evidensbaserad praktik för lärande och utveckling i välfärdsorganisationer
}

\author{
Karin Alexanderson
}

SAMMANDRAG: I sin artikel beskriver Karin Alexanderson hur en evidensbaserad praktik (EBP) skulle kunna tolkas och förstås i socialt arbete utifrån arbetets karaktär, teorier om hur man lär sig och utvecklas i sitt arbete och utifrån tidigare kunskap om implementering av EBP i välfärdsorganisationer. Några centrala frågor lyfts fram som nödvändiga att beakta vid utvecklandet av EBP i socialt arbete: hur tillgängliggörs forskningsresultat i det dagliga arbetet med individer, vilken roll har professionen vid tolkning och tillämpning, hur följs arbetet upp på individ- och gruppnivå och hur används sådant resultat och hur ser de organisatoriska förutsättningarna ut för detta? En tänkbar modell för detta föreslås. EBP ses som en process där olika typer av kunskap bejakas. Frågan kanske inte är om det är en evidensbaserad praktik som eftersträvas eller inte utan snarare om organisationen är förmögen att erbjuda och utveckla en verksamhet som stödjer kompetenta socialarbetare att använda bästa tillgängliga kunskap på ett moget och förnuftigt sätt i dialog med de människor som behöver hjälp.

NYCKELORD: evidensbaserad praktik; evidens; socialt arbete; välfärdsorganisationer; evidensbaserad policy; implementering.

PUBLICERINGSHISTORIK: Originalpublicering.

KARIN ALEXANDERSON är fil.dr i socialt arbete vid Uppsala universitet.

E-POSTADRESs: karin.alexanderson@soc.uu.se

FÖRSLAG PÅ KÄLLANGIVELSE:

Alexanderson, Karin (20I6) "Evidensbaserad praktik för lärande och utveckling i välfärdsorganisationer", i Arkiv. Tidskrift för samhällsanalys, nr 6, s. 39-57.

DOI: http://dx.doi.org/IO.I3068/2000-6217.6.2

(C) Karin Alexanderson/Arkiv förlag \& tidskrift 2016 (publicerad 7 oktober 20I6)

Artikeln distribueras enligt en upphovsrättslicens från Creative Commons:

Erkännande-Ickekommersiell-IngaBearbetningar 3.0 Unported, som medger fri ickekommersiell användning och spridning i oförändrat skick så länge källan anges. 
Arkiv. Tidskrift för samhällsanalys är en sakkunniggranskad vetenskaplig tidskrift för samhällsvetenskap och historia. Samtliga artiklar publiceras fritt tillgängliga på:

www.tidskriftenarkiv.se

Beständig länk, DoI: http://dx.doi.org/IO.I3068/2000-62I7

Den här artikeln finns tillgänglig i följande format:

PDF \& HTML: via beständig länk, DOI: http://dx.doi.org/IO.I3068/2000-6217.6.2 EPUB: ingår i e-boksutgåva av numret, ISBN: 978 9I 79242794

TRYCK: ingår i bokutgåva av numret, ISBN: 978 9I 7924280 O

Grafisk utformning och sidnumrering är identisk i pdf och tryck.

Samtliga artiklar i nr 6 (20ı6) nås via beständig länk, DOI: http://dx.doi.org/I0.I3068/2000-6217.6

Arkiv. Tidskrift för sambällsanalys ISSN: 2000-62I7 (för elektronisk resurs)

ISSN: 2000-6225 (för tryckta nummer)

ges ut av

Stiftelsen Arkiv för främjande och spridning av samhällsvetenskaplig och historisk forskning

genom

Arkiv förlag \& tidskrift

Box 1559

SE-22I OI Lund

ВESÖK: L Gråbrödersg 3 c, ipg

TEL: 046-I3 3920

ARKIV FÖRLAG: arkiv@arkiv.nu·www.arkiv.nu

TIDSKRIFTEN ARKIV: red@tidskriftenarkiv.se · www.tidskriftenarkiv.se

ANSVARIg UTGIVARE \& CHEFREDAKTÖR: Sven Hort

ADMINistrativ RedAKTÖr: David Lindberg

ReDAKTörer: Paavo Bergman, Lisa Kings, Zhanna Kravchenko 


\title{
Evidensbaserad praktik för lärande och utveckling i välfärdsorganisationer
}

\author{
KARIN ALEXANDERSON
}

När vi går till doktorn tar vi för givet att doktorn vet vad som hjälper. Men hur är det med den saken i socialt arbete? Hur vet de yrkesverksamma vad som hjälper och kan medborgarna lita på att socialarbetarna vet vad det gör?

Evidensbaserad praktik (EBP) har på senare år diskuterats såväl $\mathrm{i}$ Sverige som internationellt som en möjlighet att minska risken för godtycke och säkra en god kvalitet i arbete med människor (Avby 2015; Mullen 20I4; Svanevie 20II; Socialstyrelsen 2008; SOU 2008:18; Thyer $\&$ Myers 20II). Det råder dock osäkerhet och delade meningar om vad begreppet "evidensbaserad" kan tänkas innebära i det sociala arbetets vardag. Är en evidensbaserad praktik möjlig, och är den eftersträvansvärd (Avby 20I5; Eliasson 20I4; Shlonsky \& Mildon 20I4; Lundström \& Shanks 20I3; Bergmark \& Lundström 20IIb)?

Låt mig från början göra klart att jag, som är socialarbetare sedan många år, anser att det sociala arbetets kunskapsgrund behöver stärkas och tydliggöras. Frågan är om en evidensbaserad praktik kan bidra till detta. I den här artikeln beskriver jag hur en evidensbaserad praktik skulle kunna tolkas och förstås i socialt arbete, med tanke på arbetets karaktär, med grund i teorier om hur man lär sig och utvecklas i sitt

Artikeln är en omarbetad och utvecklad version av två tidigare texter: Alexanderson 2012 och 2009 . 
arbete och utifrån tidigare kunskap om implementering av EBP i sådana organisationer.

Den evidensbaserade praktiken, med medicinen som förebild, har den enskilda professionella i fokus snarare än organisations- eller policynivån - professionella med stort kunnande som arbetar autonomt (Connell, Fawcett \& Meagher 2009). Den förefaller ha haft svårt att få genomslag inom socialt arbete. I socialtjänsten är vissa beslut delegerade till socialarbetarna men många beslut fattas av chefer på olika nivåer eller av en politisk nämnd. I en nyligen publicerad avhandling fann Avby att socialsekreterare inom barnavårdsområdet hellre baserade sina beslut och sitt agerande på sina egna erfarenheter och kollegornas kunskaper än på forskningsrön (Avby, Nilsen \& Ellström 2015).

Det är sådant som den evidensbaserade praktiken är tänkt att motverka. Socialstyrelsen fick 2000 i uppdrag att (Socialstyrelsen 2000, s. 122):

skapa en struktur för systematisk kunskapsuppbyggnad och effektiv informationsspridning så att socialtjänstens insatser i större utsträckning kan baseras på vetenskap och beprövad erfarenhet. En viktig del i programmet är att ge empirisk och verksamhetsrelaterad forskning en större betydelse i kunskapsuppbyggnaden inom socialtjänsten.

Vid ett försök att implementera EBP inom äldreomsorgen framgick att det saknades evidensbaserade metoder inom äldreomsorgen. Det saknades strukturer som gjorde det möjligt för medarbetarna att arbeta utifrån en evidensbaserad praktik. Undersköterskorna saknade organisatoriska förutsättningar i form av tid och resurser och var inte heller vetenskapligt skolade (Abrahamson Löfström 2015).

\section{Syfte och disposition}

Med den här artikeln vill jag bidra till en förståelse av fenomenet evidensbaserad praktik i socialt arbete som i större utsträckning kan vara gemensam för de fält där socialt arbete bedrivs.

Först diskuterar jag fenomenet EBP. Därefter beskriver jag vad som karaktäriserar det sociala arbetet med individer och socialtjänsten som organisation samt lägger fram en teori om lärande och kompetens- 
utveckling i arbetslivet. Slutligen beskriver jag tre modeller för implementering av EBP. De centrala aspekterna av dessa modeller pekar på förhållanden som bör beaktas vid implementeringen av evidensbaserad praktik och vilka nivåer i en organisation som kan tänkas bli inblandade.

Artikeln rör socialtjänstens kärnverksamheter inom individ- och familjeomsorgen (IFO), det som kallas myndighetsutövning. Men det är troligt att resonemanget går att tillämpa på andra verksamheter inom det sociala fältet där människor arbetar med människors sociala situation.

\section{Vad är evidensbaserad praktik?}

Med "evidens" avsågs på 1960-talet, när evidensbaserad medicin introducerades, vetenskaplig bevisning på empirisk grund för att en metod eller ett arbetssätt har effekt och inte orsakar skada. Bevisningen kan ha högre eller lägre trovärdighet. Högst trovärdighet ger metaanalyser av resultat från flera RCT-studier (randomiserade kontrollerade försök). Därefter följer i fallande skala enskilda RCT-studier, kvasiexperimentella studier, kohortstudier, fallkontrollstudier, single-system design-studier och studier av enskilda fall (Oscarsson 2009). Det har blivit vanligare med sammanställningar av flera studier, där det tydligare framgår när och för vem olika metoder är användbara samt vilka för- och nackdelar metoderna har (Shlonsky \& Mildon 20I4). Evidensbaserad praktik handlar om att införa och använda de mest effektiva (de som har högst evidens i en hierarki beroende på vilken forskningmetod som använts) behandlingsmetoderna i praktisk verksamhet.

Det innebär att forskningsresultat är en kunskapskälla av betydelse vid beslut om behandlings- och hjälpinsatser i praktisk verksamhet;ska styra beslut om behandlings- och hjälpinsatser i praktisk verksamhet. Två andra kunskapskällor som de professionella har att beakta är klientens värderingar och preferenser samt den egna professionella erfarenheten (Avby 20I5; Jergeby 2008; Oscarsson 2009; Reynolds 200I; Sackett 1997). Den professionelle är skyldig att känna till och kunna värdera forskningsresultaten samt bedöma huruvida resultatet av sammanvägningen av de tre kunskapskällorna fungerar i den aktuella klientens situation (Avby 2015; Oscarsson 2009; Thyer 20II). 
Det finns annan vetenskapligt grundad kunskap än resultat av effektstudier (evidens) - annan kunskap som behöver vägas in i arbetet med att hjälpa människor att förändra sina liv - och i stället för EBP talas det ibland om EIP (evidence informed practice) (Higgins \& Canovan 20I4; Shlonsky \& Meldon 20I4; Alexanderson, Beijer, Hyvönen, Karlsson \& Marklund 20I2). I människobehandlande verksamhet kan det behövas kunskap om till exempel bemötande och samtalsmetodik; sociala problem som missbruk, beroende, våld och mobbning; människors utveckling samt risk- och skyddsfaktorer. Metoder kan faktiskt ha begränsad betydelse för utfallet för enskilda klienter i förhållande till andra påverkansfaktorer (Bergmark \& Lundström 20IIa; Blomqvist 2009; Oscarsson 2009). Det skulle kunna innebära att metodtroheten kan tillmätas mindre betydelse och kraven på användning av manualbaserade interventioner kan sänkas, till förmån för en större tonvikt på exempelvis en positiv behandlingsallians (Bergmark \& Lundström 20ıа; 20IIb).

Jag och andra ifrågasätter i vilken utsträckning det över huvud taget är möjligt att få tillförlitlig evidens för metoder i socialt arbete (Bergmark \& Lundström 2oırb; Billinger 20I0; Lundström \& Bergmark 2007; Oscarsson 2009). Att testa metoder experimentellt är förknippat med en rad svårigheter. Helst ska försökspersonerna slumpmässigt delas in i behandlingsgrupper och kontrollgrupper, men det strider mot principen att människor har rätt att få den bästa hjälpen. Det är inte råttor det handlar om, utan till exempel utsatta barn och människor med missbruksproblem. Andra faktorer ska hållas konstanta så att man vet att eventuella effekter faktiskt beror på den behandling man testar. Det finns mindre extrema designer, men då får resultaten svagare evidens. Det är därför en tolkning måste göras: För vem och under vilka omständigheter är den här metoden effektiv? Det är detta som en socialarbetare förväntas kunna avgöra i en evidensbaserad praktik, samtidigt som det kan finnas lagar som styr eller resurser som i praktiken avgör vilken hjälp som kan ges.

Ett evidensbaserat socialt arbete innebär att socialarbetaren i en beslutssituation tolkar och väger samman forskningsresultat med klientens historia, livssituation, erfarenheter och åsikter, men också tar hänsyn till lagstiftning och praxis samt sina egna erfarenheter och kunskaper - 


\section{Faktorer som inverkar när man tillämpar EBP $i$ socialt arbete}

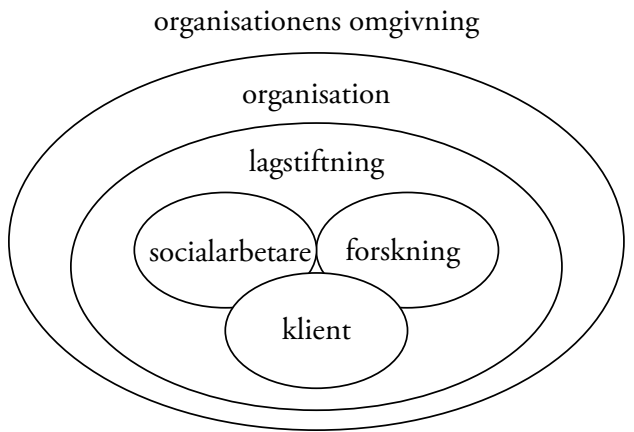

allt i förhållande till de förutsättningar (resurser, tid, utbildning, arbetsbelastning och så vidare) som den aktuella organisationen ger. EBP är i den bemärkelsen en process, ett arbetssätt, ett förhållningssätt (Shlonsky \& Mildon 20I4; Thyer 20II). Avby (20I5) beskriver en liknande modell för EBP som i figuren ovan men sätter socialarbetarens kunskaper och lärande i fokus. I övrigt lyfter hon fram organisationens (kultur, normer, lagstiftning, tekniska system) och omgivningens betydelse samt en vidare tolkning av kunskapsbegreppet.

Socialtjänsten styrs och påverkas av politiskt tillsatta nämnder med uppgift och skyldighet att besluta i enskilda ärenden utifrån en lagstiftning som återspeglar normer och värderingar hos de folkvalda - något som kan tänkas vara ett problem i ett evidensbaserat arbete. Läkare och sjuksköterskor förutsätts kunna sitt yrke och inga sjukvårdpolitiker lägger sig i deras bedömningar så länge de inte begår några allvarliga fel, men att lindra eller avhjälpa sociala problem och social misär är inte lika fritt från värderingar (Pettersson 20II; Hasenfeld 1983; 2000; Levin 1998). Samhällsproblem kommer till uttryck i enskilda människors livssituation, och individens livsvillkor avgör ofta hur utsatt hon är och vilka möjligheter hon har att få hjälp. Fattigdom och övergrepp kan ta sig kroppsliga och psykiska uttryck, men myndigheter eller vårdapparaten förväntas lösa människors problem på individnivå när den mest effektiva lösningen kanske ligger på ett samhälleligt eller politiskt plan. Den 
australiensiska forskaren Karen Healy menar att socialarbetare, i brist på kunskap om hur man bäst hjälper exempelvis barn och familjer, ägnar sig åt riskbedömningar utifrån forskning om risk- och skyddsfaktorer i stället för att ge hjälp och stöd (Healy 2009).

För att EBP ska fungera måste de professionella ha tillgång till forskningsresultat i form av kunskapssammanställningar, databaser, riktlinjer, handböcker med mera. Det finns system för informationsförsörjningen på universiteten och inom hälso- och sjukvården, men inte inom socialtjänsten. Det aktualiserar betydelsen av de organisatoriska förutsättningarna för evidensbaserad praktik. EBPP (evidensbaserad praktik och policy) omfattar organisationens ansvar för vilka metoder och arbetssätt som används (Nutley, Walter \& Davies 2007; Svanevie 20II). EBM (evidence-based management) lyfter fram ledarskapets betydelse för utvecklandet av EBP (Dill \& Shera 2012; Holmberg, Fridell, Arnesson \& Backvall 2008; Svanevie 20I3).

EBP enligt medicinsk modell är bara delvis tillämplig inom socialt arbete, som inte handlar om att ställa diagnoser utan om att ringa in en komplex problembild - en problembild som den hjälpbehövande själv behöver diskutera, förhandla om och förstå för att någon förändring ska kunna komma till stånd. Så långt som möjligt är det naturligtvis viktigt att socialtjänsten vet vilka metoder och arbetssätt som brukar fungera, men EBP är troligen mer relevant på policynivå, alltså att organisationen, i detta fall socialtjänsten, bara godkänner metoder och arbetssätt som det finns kunskapsstöd för.

I avsaknad av kunskap från vetenskapligt framtagen evidens är systematisk uppföljning och utvärdering på individ- och gruppnivå ett sätt att bygga lokal kunskap (se Petersén 2015). Men inte bara det - det är oetiskt att inte följa upp om insatser har givit avsett resultat, vare sig det finns vetenskaplig kunskap eller ej. Att en insats har stöd i vetenskapen är ingen garanti för att den hjälper en enskild klient.

I Sverige har EBP beskrivits som ett top down-initiativ från staten, något som inte efterfrågats av verksamma på fältet (Lindgren 20I5; Bergmark, Bergmark \& Lundström 20I2). Staten har eftersträvat högre effektivitet i välfärdssektorn. Bättre beslut på bättre grunder. Var och en av de professionella ska bli effektivare och fatta beslut i enlighet med 
bästa evidens om vilka insatser som är bäst. I den bemärkelsen kan pläderandet för EBP ses som en statlig kvalitetsstyrning i new public management-anda: den offentliga sektorn ska bli mer affärsmässig (Avby 2015; Lindgren 2015; Petersén \& Olsson 2015). Brukarna/klienterna ska ha valfrihet att välja. Konkurrensutsättning och jämförelsetal ska göra verksamheten effektivare. Det så kallade granskningsamhället har drivits allt längre och Lindgren befarar att mätningarna, vars kvalitet i sig kan vara tveksam, för större inflytande på politikers beslut på bekostnad av de professionellas kunskaper (Lindgren 20I4, s. 272). Kanske har det drivits så långt så långt, menar Hasenfeld, att människor som behöver samhällets hjälp inte längre får det för att de är svårbehandlade eller olönsamma (2015).

\section{Socialt arbete i socialtjänsten}

Åtskilliga försök har gjorts att beskriva det sociala arbetet som praktik, i teoretiska termer och som vetenskaplig disciplin (se till exempel Bergmark 1998; Bernler \& Johnsson 200I; Börjesson 2008; Dominelli 2004; Meeuwisse m.fl. 2000; Payne 1996; Pettersson 200I; Tham 2007). Jag kommer i det här avsnittet att gå igenom hur det sociala arbetet i svensk socialtjänst karaktäriseras och beskrivs av dem som har studerat det empiriskt (se Alexanderson 2006; Baianstovu 2012). Fokus ligger på det individuella sociala arbete som utförs inom missbruks- och barn- och familjeområdet inom socialtjänstens individ- och familjeomsorg (IFO). Vissa drag återkommer i arbetet inom alla socialtjänstens kärnverksamheter.

När klienten söker bistånd eller anmäls till socialtjänsten görs först en förhandsbedömning och sedan inleds en social utredning som ska ge en bild av klientens situation samt bedöma hens resurser och behov. På grundval av utredningen som grund fattas biståndsbeslutet, och därefter följer en eventuell insats.

Fullt så rationellt fungerar dock utredningsarbetet sällan. Mycket händer under utredningens gång som inte framgår av utredningstexten och exempelvis en barnavårdsutredning kan därför också betraktas som en förändringsprocess (Hyvönen \& Forsgren 2000). 
ARKIV | NR 6

Vid litteraturgenomgången har jag identifierat fyra huvudsakliga arbetssätt inom IFO-verksamheter:

- åtgärdande

- administrerande

- förhandlande, medlande, synliggörande av tolknings- och handlingsmöjligheter

- behandlande.

Socialt arbete kan ha inslag av alla fyra arbetssätten samtidigt - de finns så att säga i socialarbetararsenalen. De förhandlande och behandlande arbetssätten kräver ett samarbete med klienten för att en förändring ska vara möjlig. Hur arbetet med en specifik klient gestaltar sig beror på arbetsuppgiftens art och klientens behov, och intensiteten kan också variera över tid. Att skapa kontakt och en relation mellan socialarbetare och klient är centralt, enligt socialarbetare själva till och med viktigare än vilken metod som används (Perlinski, Blom \& Morén 20I2).

Därutöver karaktäriseras det sociala arbetet i socialtjänsten av att

- det ofta är specialiserat

- socialarbetarna har att hantera frågor om tvång och frivillighet

- det är ett förändringsarbete, i högre eller lägre grad

- för att ge hjälp krävs ofta samverkan med andra organisationer inom välfärdsområdet.

Evidensbaserad praktik kräver att den professionella kan väga samman olika typer av kunskaper. Att en socialarbetare förhandlar, tolkar, medlar, skapa insikter och motiverar i syfte att hjälpa klienten på bästa sätt borde vara förenligt med ett sådant tänkesätt. De hjälpinsatser som sedan följer kan vara allt från avgränsade program och behandlingar (evidensbaserade eller beprövade) till olika individuella insatser som avlöser eller går i varandra. Att socialarbetare är specialiserade borde göra att de kan ha fördjupade och ämnesspecifika kunskaper från exempelvis forskning inom sitt område. Baksidan av specialiseringen är att de inte ser klientens hela livssituation (Morén, Perlinski \& Blom 2015). Gällande lagstiftning anbefaller en helhetssyn på människors problem, och samverkan mellan socialtjänstens enheter är en utmaning. 
Tillsynsmyndigheter och Arbetsmiljöverket har pekat ut den höga personalomsättningen som ett problem (Inspektionen för vård och omsorg 20I4; Tham 2008). Den skadar inte bara klienter och socialsekreterare utan också organisationens möjligheter att utveckla verksamhetens kvalitet (Lindquist 20II).

Socialt arbete i socialtjänstens myndighetsutövning kan ses som väldigt säreget. Möjligheten att ingripa i människors liv mot deras vilja ställer höga krav på att man "vet vad man gör". Socialt eller kurativt arbete kan ha förhandlande inslag även i andra organisatoriska sammanhang. Man förhandlar med sina klienter om hur deras situation ser ut för att uppnå en gemensam förståelse av deras problem. Det är en förutsättning för att åstadkomma mänsklig förändring.

\section{Vad som kännetecknar en välfärdsorganisation}

Välfärdsorganisationer har vissa gemensamma drag, som har betydelse för implementeringen av EBP. I en välfärdsorganisation arbetar människor med människor i syfte att skydda, bibehålla eller förbättra välfärden för individer eller grupper av individer (Johansson, Dellgran \& Höijer 2015). Socialarbetaren är en nyckelperson i organisationen eftersom det är i mötet med klienten som det sociala arbetet uppstår. Den professionella socialarbetarens personliga attityder, värderingar och samhällssyn kommer till uttryck i handlingar i organisationens namn (Ahrne 1999; Hasenfeld 2000). Socialarbetaren har ett visst handlingsutrymme (Jones \& May 1992; Lipsky 1980). Det kan vara på gott och ont, det ger frihet och är i vissa delar nödvändigt för en självständigt arbetande professionell, men det kan också upplevas som brist på stöd (Alexanderson 2006). En välfärdsorganisation kännetecknas av en rad osäkerheter i process och utförande: oklara mål samt svårigheter att mäta resultat och att visa organisationens effektivitet (Hasenfeld 1983). Om det är oklart huruvida metoder och arbetssätt är effektiva tenderar de att ersättas med nya, och då snarare baserat på ideologi än på evidens (Jones \& May 1992).

Begreppet "löst kopplade system" återkommer i beskrivningar av välfärdsorganisationer (Weick 1976; Hasenfeld 1983; Ahrne 1994; Røvik 2000). Lös koppling innebär att enheter eller grupper i en organisation 
arbetar förhållandevis självständigt eller fungerar som autonoma aktörsgrupper i en organisation. Det kan vara svårt för organisationen att styra eller få inflytande i sådana självständiga grupper. Ledningen har ofta begränsad insyn i delar av verksamheten (Hasenfeld 1983; Røvik 2000). Resultaten av arbetet tenderar att bli osynliga eller ignorerade $i$ välfärdsorganisationer. Mänsklig förändring är inte så lätt att beskriva i resultattermer på verksamhetsnivå (Hasenfeld 1983; Sunesson 1985; Ahrne 1994).

\section{Lärande och utveckling}

Att arbeta i en evidensbaserad praktik innebär enligt min uppfattning att hålla sig ajour inom sitt område och vara intresserad av att lära nytt, att utvecklas. Ellström skiljer mellan kompetens (det att kunna genomföra sina arbetsuppgifter) och kvalifikation (det att ha en relevant utbildning och kunskap om hur arbetet ska bedrivas). Kvalifikationskrav ställs av arbetsgivaren, kompetensen utgår från individens "potentiella förmåga i relation till ett visst arbete" (I992, s. 30). En individ kan ha en rad kompetenser som inte utgör formella kvalifikationer för ett visst arbete, eller kan ha rätt kvalifikationer men sakna erforderlig kompetens (a.a.). En yrkeskompetens formas av utbildning, vetenskaplig kunskap och yrkesoch livserfarenheter men också av individens personliga egenskaper och förmågor (Ellström 200I). Kompetensen måste underhållas, och ny kunskap och evidens utvecklas och tillkommer hela tiden vilket gör att tidigare förvärvad kunskap kan behöva revideras.

I dagens arbetsliv ses arbete och lärande som två sidor av samma mynt $\mathrm{i}$ ambitionen att utveckla verksamhet och individer (Ellström 200I). Ellström urskiljer tre aspekter av det goda lärandet:

- bemästringslärande eller anpassningslärande, att lära sig på förhand definierade kunskaper, rutiner och tankesätt

- lärande som utveckling av ett personligt förhållningssätt, att internalisera kunskapen och göra den till sin egen

- ett utvecklingsinriktat och kreativt lärande som innebär nyskapande och utveckling. 
För att uppnå det goda lärandet måste man kunna utföra rutinbetonade uppgifter samtidigt som man hanterar nya situationer (a.a.). Individer som lär i arbetslivet gör det som delar av en organisation. Även organisationer kan enligt Ellström ägna sig åt bemästringslärande och utvecklingslärande, vilka präglas av produktionens respektive utvecklingens logik. Produktionens logik är förknippad med rutiner och regler i syfte att effektivt producera varor eller tjänster. Utvecklingens logik främjar kreativitet, reflektion och nytänkande - men överskuggas ofta av produktionens logik. En öppenhet för lärande förutsätter en balans mellan de båda logikerna (Ellström 200I). Med hänvisning till sin egen och andras forskning anger Ellström ett antal kriterier som måste vara uppfyllda för att ett förändringsarbete $\mathrm{i}$ enlighet med utvecklingens logik ska kunna äga rum: klara och tydliga mål och visioner för förändringsarbetet, delaktighet för berörda parter, tid och rum för arbete med utvecklingsfrågor, stöd från ledningen samt en kultur som understödjer lärande (Ellström 200I). Av detta kan slutsatsen dras att EBP implementeras inom ramen för utvecklingens logik och med tiden blir en del av produktionens logik. Utvecklingens logik kräver engagemang från flera nivåer i en organisation, inte bara de enskilda professionella utan även ledare och beslutsfattare: en idé om varför och en genomtänkt policy för hur en evidensbaserad praktik ska tolkas och förstås i organisationen.

I nästa avsnitt presenteras tre olika modeller eller beskrivningar för implementering av EBP, eller i vidare mening vad som krävs för att forskningsresultat ska komma till användning, i välfärdsorganisationer.

\section{Att införa och tillämpa EBP i välfärdsorganisationer}

Austin och Claassen (2008), Mullen m.fl. (2008) och Nutley m.fl. (2007) har skrivit om implementering av EBP i välfärdsorganisationer, eller i vidare mening vad som krävs för att forskningsresultat ska komma till användning i sådana organisationer. Austin och Claassen skriver om olika nivåer i en organisation där forskning används, Mullen om strategier för forskningsanvändning och Nutley m.fl. om modeller för forskningsanvändning. Jag sammanfattar dem i tablån på s. 52 . 
Austin och Claassen (2008) talar om en mikronivå (individnivå) och en makronivå (systemnivå) samt en kombination av de två nivåerna. På mikronivån finns de professionella - enskilda handläggares attityder, handlingar och behov samt deras förmåga att tolka och använda evidens. På makronivån finns organisationens policy och struktur för nyckelprocesser (till exempel riktlinjer, arbetssätt, metoder, utbildning och övning). Enligt Austin och Claassen kräver implementeringen av EBP en organisationskultur som möjliggör och premierar gott ledarskap, planering och involvering av alla nivåer i organisationen.

Mullen m.fl. har identifierat fem strategier för spridning och implementering av EBP (2008), varav de första tre anknyter till Austin och Claassens tre nivåer. Den första strategin är att utbilda de professionella i EBP: lära dem att formulera rätt fråga, att söka och bedöma evidens, att väga samman evidensen med klientens resurser, önskemål och situation samt att utvärdera utfallet för klienten. Den andra strategin är att påbjuda riktlinjer, rutinbeskrivningar och manualbaserade metoder. Den tredje strategin är en kombination av strategier på mikro- och makronivåerna. Den färde strategin kan utvecklas när forskningsevidens saknas; då får man nyttja lokal uppföljning och professionens beprövade erfarenhet (empirically supported interventions). Den femte strategin är att utveckla professionens gemensamma kunskapsbas genom att beskriva och sprida den beprövade erfarenheten, enas om och acceptera innehållet som lokal evidens samt implementera denna och följa upp effekten.

Nutley m.fl. (2007) beskriver tre modeller för forskningsanvändning. Den första bygger på forskningsbaserade praktiker (research based practitioner model): den enskilda professionella håller sig ajour med relevant forskning och förutsätts kunna fatta självständiga beslut som tillgodoser klienternas behov. Forskaren producerar kunskap och praktikern konsumerar den. Det är avgörande att praktikern har fått utbildning och övning i att tillämpa forskningsresultat i sitt arbete och har tillgång till dem, ofta i elektronisk form. Några hinder för att denna modell ska fungera inom IFO är att socialarbetarnas självständighet begränsas av lagstiftning och politiska nämnder, att det råder brist på evidens för metoder inom socialt arbete och att arbetet till sin natur är förhandlande. 
Den andra modellen bygger på att forskningsresultat eller evidens finns inbakade i organisationens policy (embedded research model): resultat från forskning byggs in i strukturer och system. Organisationen accepterar endast metoder och modeller som anses ha stöd i evidens. Individens lärande och reflekterande minskar i betydelse. Denna modell förefaller vara svår att förena med ett förhandlande, tolkande, motiverande och medlande socialt arbete där klientens uppfattningar och den professionellas roll tillmäts stor betydelse.

Den tredje modellen bygger på organisatorisk excellens (organisational excellence model) och betonar samarbetet mellan politiker, ledare inom organisationen och professionella som aktörer i en lärande organisation. Universitet, forsknings- och utvecklingsenheter och liknande organisationer samverkar. Förutom resultat från effektstudier används även andra forskningsresultat samt lärdomar från den egna lokala praktiken. Organisationen konsumerar inte bara kunskap utan producerar den också genom att utföra försök, utvärderingar och forskningsbaserat utvecklingsarbete. Denna modell tar hänsyn till både professionens roll och organisationens policyskapande funktion, och ger förutsättningar för lärande och utveckling. Även om det finns evidens för en viss intervention, och särskilt om det saknas evidens, behövs en praktiker som kan väga samman flera kunskapskällor och planera vad som ska ske, hur och när, med klientens bästa för ögonen. Det kan innebära att hjälpinsatsen blir en annan än vad evidensen pekar mot. Beslut, insatser och utfall dokumenteras systematiskt så att organisationen kan dra lärdom av vad som har fungerat och inte (beprövad erfarenhet).

Verklighetens forskningsanvändning liknar oftast någon hybrid av de tre modellerna. Det kan gälla över tid där den första modellen är den ursprungliga som sedan utvecklas till den andra för att sedan bli den tredje. Det finns inget belägg för att modellerna skulle se olika ut för utvecklingsarbete och implementeringsarbete och det finns inte heller någon modell som passar i alla sammanhang (Nutley m.fl. 2007, s. 219,226$)$. 
ARKIV | NR 6

Nivåer, strategier och modeller för implementering av EBP

\begin{tabular}{|c|c|c|c|}
\hline 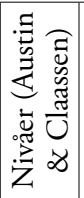 & $\begin{array}{l}\text { Mikronivån (den } \\
\text { enskilda professionella) }\end{array}$ & $\begin{array}{l}\text { Makronivån (organisa- } \\
\text { tionen och dess policy) }\end{array}$ & $\begin{array}{l}\text { En kombination av } \\
\text { nivåerna }\end{array}$ \\
\hline 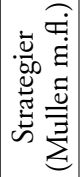 & $\begin{array}{l}\text { I. Formulera frågor, söka } \\
\text { och kritiskt bedöma evi- } \\
\text { dens, tillämpa den och } \\
\text { utvärdera resultatet }\end{array}$ & $\begin{array}{l}\text { 2. Evidensbaserad policy } \\
\text { 4. Beprövad erfarenhet } \\
\text { 5. Utveckla professio- } \\
\text { nens kunskapsbas }\end{array}$ & $\begin{array}{l}\text { 3. Kombination av stra- } \\
\text { tegi } \mathrm{I}-5\end{array}$ \\
\hline 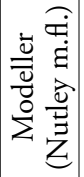 & $\begin{array}{l}\text { Fokus på den enskilda } \\
\text { professionella som } \\
\text { forskningsanvändare }\end{array}$ & $\begin{array}{l}\text { Fokus på organisatio- } \\
\text { nen som garant för } \\
\text { forskningsanvändning }\end{array}$ & $\begin{array}{l}\text { Fokus på en lärande } \\
\text { organisation, bred } \\
\text { kunskapssyn }\end{array}$ \\
\hline
\end{tabular}

\section{Sammanfattande diskussion}

Det råder ingen tvekan om att socialt arbete, som numera dessutom är en vetenskaplig disciplin, bör ha sin grund i vetenskap och beprövad erfarenhet. Medborgarna måste kunna lita på att det sociala arbetet är en garant för kvalitet. Evidensbaserad medicin uppstod på 1960-talet ur en historia då läkarna hade förlitat sig mer på sina kollegor och läkemedelsföretagens beskrivningar än på forskningsresultat. $\mathrm{Nu}$ finns anledning att skapa en egen förståelse av det sociala arbetets praktik som kunskapseller evidensbaserad.

Den som vill utveckla en syn på vad en evidensbaserad praktik som kan vara gemensam för hela fältet socialt arbete innebär måste beakta många perspektiv. Det har jag försökt göra i den här artikeln. Vad innebär det att hävda att en socialtjänst arbetar evidensbaserat om man ser till det sociala arbetets karaktär, till socialtjänsten som en människobehandlande organisation, till hur forskning används i sådana organisationer och till hur man lär sig och utvecklas i sitt yrke?

För att tillämpa evidensbaserad praktik behöver socialarbetaren hålla sig ajour med aktuell forskning inom sitt område. Det kan vara forsk- 
ningskunskap i vid mening, inte bara evidens som rör ens specifika verksamhet. Vilka metoder och arbetssätt som ska användas kan inte vara upp till enskilda socialarbetare. Metoder och arbetssätt som en organisation tillhandahåller måste ha granskats och befunnits vara vetenskapligt hållbara, och det måste ha fattats beslut om att de ska införas och hur, och inte minst hur arbetet ska följas upp. Uppföljningarna dokumenteras systematiskt och kan så småningom utvecklas till beprövad erfarenhet som kan prövas av andra och prövas vetenskapligt.

Såväl den professionella nivån som organisationsnivån behöver involveras i den evidensbaserade praktiken. Rutiner och strategier för hur lärande och utveckling byggs in i organisationen kan också skapa förutsättningar för att få behålla personal. Socialarbetarna blir då inte bara en del av produktionens logik utan en viktig kugge i uppföljningen och utvecklingen av arbetet, och de får använda sin professionalitet. För att hjälpen ska bli bra behövs förutom forskning och beprövad erfarenhet även klienternas synpunkter på och erfarenheter av sin egen situation. Att väga samman dessa kunskapskällor samtidigt som man skapar en relation med de människor man möter är en utmaning, men som jag ser det en nödvändighet.

Det finns ingen kunskap om huruvida EBP i sig ger ett bättre arbete eller utfall för dem som verksamheten är till för. Det är naturligtvis svårt att följa upp och värdera om man inte är överens om tolkningen av företeelsen. Den stora frågan kanske inte är om det är en evidensbaserad praktik som eftersträvas eller inte utan snarare om socialtjänsten är förmögen att erbjuda och utveckla en verksamhet som stödjer kompetenta socialarbetare att använda bästa tillgängliga kunskap på ett moget och förnuftigt sätt i dialog med de människor som behöver hjälp.

\section{Referenser}

Abrahamson Löfström, Carina (2015). Kunskapsstyrning i äldreomsorg. Implementering av och samarbete kring evidensbaserad praktik. FoU Väst, rapport nr 3 . URL: http://www.grkom.se/download/18.5296b362I4fdd3b9f2I27f2e/I442573879075/ kunskapsstyrning_evidensbaserad_praktik_äldreomsorgen.pdf (8 september 20I6) Avby, Gunilla (2015). Evidence in practice. On knowledge use and learning in social work. Linköping: Linköpings universitet. 
Avby, Gunilla, Nilsen, Per \& Ellström, Per-Erik (2015). "Knowledge use and earning in everyday social work practice: a study in child investigation work". Child and Family Social Work. DOI: http://doi.org/IO.IIII/cfs.I2227

Alexanderson, Karin (2006). Vilja, kunna, förstå. Om implementering av systematisk dokumentation för verksamhetsutveckling $i$ socialtjänsten. Örebro: universitetsbiblioteket.

Alexanderson, Karin (2009). ”Forskningsstyrd eller forskningsstödd - om FoU-miljöers roll i en evidensbaserad praktik". I Tydén, Thomas (red.), Gott och blandat. Om FoUmiljöer i kommuner, landsting och regioner. Falun: Dalarnas forskningsråd.

Alexanderson, Karin (2012). Socialtjänstens förutsättningar att utveckla en evidensbaserad praktik. Falun: Dalarnas forskningsråd.

Alexanderson, Karin, Beijer, Elisabeth, Hyvönen, Ulf, Karlsson, Per-Åke \& Marklund, Kristin (2012). "Let's come together. A macro-oriented model for organizing the support of evidence-based practice". I Dill, Katharine \& Shera, Wes (red.), Implementing evidence-informed practice. International perspectives. Toronto: Canadian scholars' press.

Alexanderson, Karin \& Jess, Kari (20I5). Stuprör, hängrännor och rännkrokar. Utvärdering av projektet Samordnat stöd till barn och föräldrar i familjer med missbruk 2013-20I4. Kalmar: Nationellt kompetenscentrum anhöriga.

Ahrne, Göran (1994). Social organizations. Interaction inside, outside and between organizations. London: Sage.

Ahrne, Göran (1999). ”Organisationer och människor”. I Ahrne, Göran \& Hedström, Peter (red.), Organisationer och sambälle. Analytiska perspektiv. Lund: Studentlitteratur.

Austin, Michael \& Claassen, Jennette (2008). "Implementing evidence-based practice in human service organisations. Preliminary lessons from the frontline". Journal of Evidence-Based Social Work, vol. 5, nr I. DoI: http://doi.org/IO.I300/J394VO5noI_Io

Baianstovu, Runa (2012). Mångfald som demokratins utmaning. En studie av hur socialtjänsten som välfärdsbyråkrati och moralisk sambällsinstitution förstår och hanterar kulturell mångfald. Örebro: Örebro universitet.

Bergmark, Åke (1998). Nyckelbegrepp i socialt arbete. Lund: Studentlitteratur.

Bergmark, Anders \& Lundström, Tommy (20IIa). "Socialstyrelsen, dronten och den evidensbaserade praktiken". Socialvetenskaplig tidskrift, nr 3 .

Bergmark, Anders \& Lundström, Tommy (20IIb). "Evidensbaserad praktik i svenskt socialt arbete. Om ett programs mottagande, förändring och möjligheter i en ny omgivning”. I Bohlin, Ingemar \& Sager, Morten (red.), Evidensens många ansikten. Evidensbaserad praktik i praktiken. Lund: Arkiv förlag.

Bergmark, Anders, Bergmark, Åke \& Lundström, Tommy (20II). Evidensbaserat socialt arbete. Teori, kritik, praktik. Stockholm: Natur \& Kultur.

Bergmark, Anders, Bergmark, Åke \& Lundström, Tommy (20I2). ”The mismatch between the map and the terrain. Evidence-based social work in Sweden". European Journal of Social Work, vol. I5, nr 4. DoI: http://doi.org/I0.1080/13691457.2012.706215 
Bernler, Gunnar \& Johnsson, Lisbeth (200I). Teori för psykosocialt arbete. Stockholm: Natur \& Kultur.

Börjeson, Bengt (2008). Förstå socialt arbete. Malmö: Liber.

Higgins, Kathryn, Canavan, John \& Coen, Liam (2014). "Mapping the field in evidence informed policy and practice: international perspectives". Evidence \& Policy, vol. Io, $\mathrm{nr} 4$.

DoI: http://doi.org/IO.I332/I744264I4XI4I4420480I909

Connell, Raewyn, Fawcett, Barbara \& Meagher, Gabrielle (2009). ”Neoliberalism, new public management and the human service professions. Introduction to the special issue". Journal of Sociology, vol. 45, $\mathrm{nr} 4$. DoI: http://doi.org/IO.II77/I440783309346472

Dill, Katharine \& Shera, Wes (2012). Implementing evidence-informed practice. International perspectives. Toronto: Canadian scholars' press.

Dominelli, Lena (2004). Social work. Theory and practice for a changing profession. Cambridge: Polity press.

Eliasson, Benita (20I4). Social work approaching evidence-based practice. Rethinking social work. Luleå: Luleå tekniska universitet.

Ellström, Per-Erik (200I). "Lärande och innovation i organisationer”. I Backlund, Thomas, Hansson, Henrik \& Thunborg, Camilla (red.), Lärdilemman i arbetslivet. Teoretiska och praktiska perspektiv på lärande i organisationer. Lund: Studentlitteratur.

Hasenfeld, Yeheskel (1983). Human service organizations. Englewood Cliffs: Prentice Hall.

Hasenfeld, Yeheskel (2000). "Organizational forms as moral practices. The case of welfare departments". Social Service Review, vol. 74, nr 3. DoI: http://doi.org/Io.I086/516408

Hasenfeld, Yeheskel (2015). "Förord”. I Johansson, Staffan, Dellgran, Peter \& Höijer, Staffan (red.), Människobehandlande organisationer. Villkor för ledning, styrning och professionellt välfärdsarbete. Stockholm: Natur \& Kultur.

Healy, Karen (2009). "A case of mistaken identity. The social welfare professions and New Public Management”. Journal of Sociology, vol. 45, nr 4.

DOI: http://doi.org/IO.II77/I440783309346476

Holmberg, Rolf, Fridell, Mats, Arnesson, Patrick \& Bäckvall, Mia (2008). ”Leadership and implementation of evidence-based practices", Leadership in Health Services, vol. 2I, $\mathrm{nr} 3$.

DOI: http://doi.org/I0.IIo8/I75II8708I089300I

Hyvönen, Ulf \& Forsgren, Nanna (2000). Klara. Om kvalitet och effektivitet $i$ det sociala arbetet med barnavardsutredningar - en processutredning av ett utvecklingsprojekt. Umeå: Umeå socialtjänst.

Inspektionen för vård och omsorg (2014). Tar socialtjänsten sitt ansvar för barn och unga? Hantering av anmälningar och genomförande av utredningar.

URL: http://www.ivo.se/globalassets/dokument/bilder-och-nyheter/20I4/tarsocialtjansten-sitt-ansvar-for-barn-och-unga.pdf (8 september 20I6)

Jergeby, Ulla (2008). Evidensbaserad praktik i socialt arbete. Stockholm: Gothia. 
Johansson, Staffan, Dellgran, Peter \& Höijer, Staffan (2015). Människobehandlande organisationer. Villkor för ledning, styrning och professionellt välfärdsarbete. Stockholm: Natur \& Kultur.

Jones, Andrew \& May, John (1992). Working in human service organisations. A critical introduction. Melbourne: Longman Cheshire.

Levin, Claes (1998). Uppfostringsanstalten. Om tvång i föräldrars ställe. Lund: Arkiv förlag.

Lindquist, Anna-Lena (20II). "Att förstå personalomsättning och kompetenstapp bland barnavårdsutredare” I Hansson, Merike (red.), Leda känslomässigt krävande arbete. För dig som är chef inom socialt arbete och omsorg. Stockholm: Gothia.

Lipsky, Michael (1980). Street-level bureaucracy. Dilemmas of the individual in public services. New York: Russel Sage Foundation.

Lindgren, Lena (2015). "Granskning för utveckling och kontroll i socialt arbete”. I Johansson, Staffan, Dellgran, Peter \& Höijer, Staffan (red.), Människobehandlande organisationer. Villkor för ledning, styrning och professionellt välfärdsarbete. Stockholm: Natur \& Kultur.

Lundström, Tommy \& Bergmark, Åke (2007). ”Att studera rörliga mål. Om villkoren för evidens och kunskapsproduktion i socialt arbete". Socionomen, nr 2I.

Lundström, Tommy \& Shanks, Emelie (2013). "Hård yta men mjukt innanmäte. Om hur chefer inom den sociala barnavården översätter evidensbaserat socialt arbete till lokal praktik". Socialvetenskaplig tidskrift, nr 2.

Meeuwisse, Anna, Sunesson, Sune \& Swärd, Hans (red.) (2000). Socialt arbete. En grundbok. Stockholm: Natur \& Kultur.

Morén, Stefan, Perlinski, Marek \& Blom, Björn (2015). ”En domänteori för organisering av socialt arbete i offentlig sektor". Socialvetenskaplig tidskrift, vol. 22, $\mathrm{nr}$ I.

Mullen, Edward J., Bledsoe, Sarah E. \& Bellamy, Jennifer L. (2008). ”Implementing Evidence-based social work practice". Research on Social Work Practice, vol. I8, nr 4. DoI: http://doi.org/IO.1177/IO49731506297827

Mullen, Edward J (2014). "Evidence-based knowledge in the context of social practice". Scandinavian Journal of Public Health, vol. 42, $\mathrm{nr}$ I3 (supplement). Dor: http://doi.org/I0.1177/I403494813516714

Nutley, Sandra M., Walter, Isabel \& Davies, H. T. O. (2007). Using evidence. How research can inform public services. Bristol: Policy Press.

Oscarsson, Lars (2009). Evidensbaserad praktik inom socialtjänsten. En introduktion för praktiker, chefer, politiker och studenter. Stockholm: SKL Kommentus.

Payne, Malcolm (1996). What is professional social work? Birmingham: Venture Press.

Perlinski, Marek, Blom, Björn \& Morén, Stefan (2012). "Getting a sense of the client. Working methods in the personal social services in Sweden". Journal of Social Work, vol. I3, nr 5 .

DOI: http://doi.org/IO.II77/I4680I731I435047

Petersén, Anna Charlotta \& Olsson, Jan Ingvar (2015). "Calling evidence-based practice into question. Acknowledging phronetic knowledge in social work". British Journal of Social Work, vol. 45, nr 5.

DOI: http://doi.org/IO.IO93/bjsw/bcuo2o 
Pettersson, Ulla (200I). Socialt arbete, politik och professionalisering. Den historiska utvecklingen i USA och Sverige. Stockholm: Natur \& Kultur.

Pettersson, Ulla (2OII). Från fattigvård till socialtjänst. Om socialt arbete och utomparlamentarisk aktivitet. Lund: Studentlitteratur.

Reynolds, Shirley (200I). "The anatomy of evidence-based practice. Principles and methods". I Trinder, Liz \& Reynolds, Shirley (red.), Evidence-based practice. A critical appraisal. Oxford: Blackwell science.

Røvik, Kjell Arne (200o). Moderna organisationer, trender inom organisationstänkandet vid millennieskiftet. Malmö: Liber.

Sackett, David L. (1997). Evidence-based medicine. How to practice and teach EBM. New York: Churchill-Livingstone.

Shlonsky, Aron \& Mildon, Robyn (20I4). "Methodological pluralism in the age of evidence-informed practice and policy". Scandinavian Journal of Public Health, vol. 42, nr I3 (supplement).

DOI: http://doi.org/I0.1177/I403494813516716

Socialstyrelsen (2000). Nationellt stöd för kunskapsutveckling inom socialtjänsten. URL: http://www.socialstyrelsen.se/publikationer200o/2000-3-I2 (8 september 2016)

Socialstyrelsen (2008). FoU-enheter med inriktning mot individ-och familjeomsorgen - en uppföljning. Stockholm: Socialstyrelsen.

SOU 2008:I8. Evidensbaserad praktik inom socialtjänsten - till nytta för brukaren. Betänkande av utredningen för en kunskapsbaserad socialtjänst.

SOU 2011:6I. Vanvård $i$ social barnavard. Slutbetänkande av utredningen om vanvård $i$ den sociala barnavairden.

Sunesson, Sune (1985). Andra allt! En uppmaning till socialarbetare. Stockholm: Liber.

Svanevie, Kajsa (2013). Socialt arbete som evidensbaserad praktik. Lund: Studentlitteratur.

Svanevie, Kajsa (20II). Evidensbaserat socialt arbete. Från idé till praktik. Umeå: Umeå universitet.

Svensson, Lennart (2002). "En analys och blick framåt”. I Svensson, Lennart, Brulin, Göran, Ellström, Per-Erik \& Widegren, Örjan (red.), Interaktiv forskning - för utveckling av teori och praktik. Stockholm: Arbetslivsinstitutet.

Tham, Pia (2008). Arbetsvillkor i den sociala barnavården. Förutsättningar för ett kvalificerat arbete. Stockholm: Stockholms universitet.

Thyer, Bruce A. \& Myers, Laura L. (20II). "The quest for evidence-based practice. A view from the United States". Journal of Social Work, vol. II, nr I. DOI: http://doi.org/I0.II77/I4680I7310381812

Weick, Karl (1976). "Educational organizations as loosely coupled systems". Administrative Science Quarterly, vol. 2I, nr I.

DOI: http://doi.org/I0.2307/2391875 


\section{PANDORA}

\section{Ingemar Bohlin \& Morten Sager (red.)}
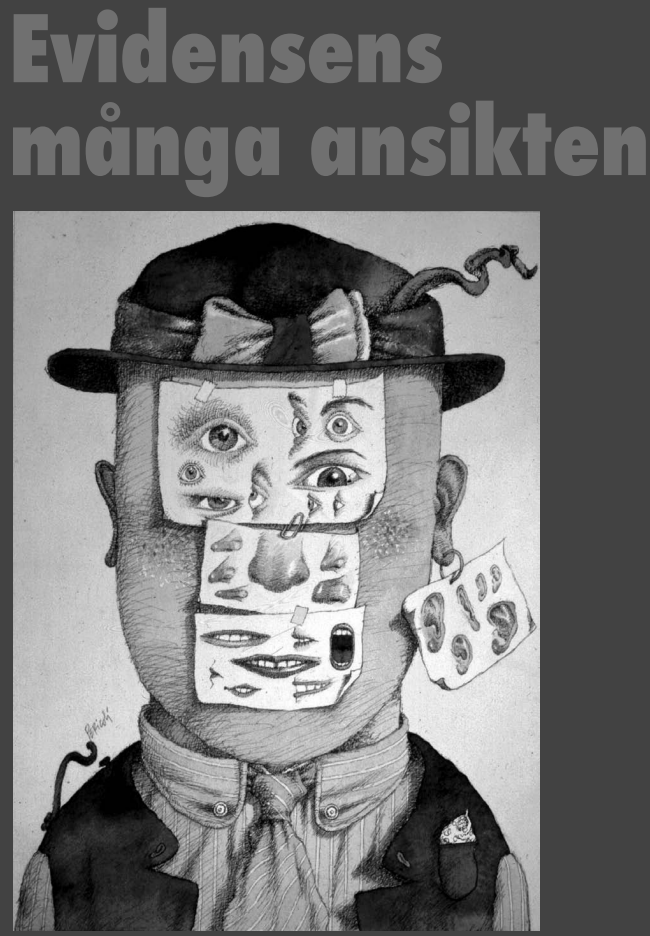

\section{Evidensbaserad praktik i praktiken}

Evidensens många ansikten vänder sig till alla som undrat vad begreppen "evidens" och "evidensbaserad praktik" egentligen står för. Den innehäller konkreta och nyanserade diskussioner som kan vägleda blivande och verksamma praktiker inom vård, skola och omsorg och ger nya insikter i frågor om hur vetenskaplig kunskap kan tillämpas i professionell praktik.

\section{Arkiv förlag, Pandoraserien, 230 sidor}

